\title{
Comparative Analysis of Universal Primary Education Policy and Progress in India and Sri Lanka in the Era of Globalization
}

\author{
Sarabjit Kaur ${ }^{1 *} \quad$ Kamaljeet Singh $^{2}$ \\ 1.Research Scholar, Department of Education and Community Service, Punjabi University, Patiala, Punjab, \\ India \\ 2.Professor, Department of Education, Punjabi University Regional Centre, Bathinda, Punjab, India
}

\begin{abstract}
Sustainable Development Goals, like previous Millennium Development Goals, put strong emphasis on the inclusive and quality education for all by 2030 and directed all the nation states to make concerted efforts to ensure this. Many developing countries after the endorsement of time-bound global goals regarding education has resulted in remarkable changes in their national education policy directions by making provisions of free and compulsory education for a stipulated period. However, even today, when the global development agenda is emphasizing inclusive and quality education for all at all levels, the goal of universal primary education remains elusive for many developing countries. The aim of this study was to analyze educational policy changes and progress in universal primary education in India and Sri Lanka under the influence of global policy agenda. India and Sri Lanka are two important countries in South Asian region and both are quite proactive in their efforts towards universalization of primary education. With the help of trend analysis method, it has been observed tremendous progress has been observed in the expansion of access of primary education in these countries. However, the results indicate that the performance of Sri Lanka in primary education is far better than India and India can learn a lot from the experiences of Sri Lanka. But, the high number of out of school children and poor learning outcomes in both the countries need a radical shift in the focus of the policy planning in these countries. The study is quite critical to highlight the glaring gaps in the provision of education for all in these countries and experiences of these countries can provide instructive lessons for other countries struggling with the goal of education for all.
\end{abstract}

Keywords: Universal Primary Education, Education for All, Educational Policy, Globalization, South Asia.

DOI: $10.7176 / \mathrm{JEP} / 11-8-04$

Publication date:March $31^{\text {st }} 2020$

\section{Introduction}

Beginning with the realization of education as a fundamental right in the Universal Declaration of Human Rights 1948 , the issue of elementary education has dominated the various international treaties as well as international development discourse. The initiatives for international cooperation for education got momentum in 1980s mainly due to the emergence of democratic regimes, rising globalization and ending of Cold War. The major effort in this direction was Jomtien Conference held in 1990, this conference considered education a fundamental human right and it was resolved that basic education should be provided to all children, youth and adults. The expanded vision of basic education presented as World Declaration on Education for All has been endorsed by more than 150 countries. However, the conference has been criticized by many that it was organized exactly for imposing the Structural Adjustment Programme (SAP) in the developing countries of the world and simultaneously reducing the government expenditure on the social sectors such as education, health etc. (Sadgopal 2006; Nudzor, 2015). The Conference is considered as starting of the globalization in the field of education. Despite of the criticism, the Jomtien Conference has been considered as a turning point in the history of education and access to schooling has been expanded to a greater extent after 1990 in many parts of the world.

After a decade from this conference, the next effort in this direction is 'World Conference on Education', held in Dakar, to reaffirm the 'Education for All' agenda. The World Education Conference in Dakar chose six main goals as the following-up to the Education for All 2000 Assessment. The Dakar Framework has been linked with Millennium Development Goals. The unfinished Millennium Development Goals are not being transformed in to Sustainable Development Goal and out of 17 Sustainable Development Goals, Goal 4 emphasizes the inclusive and quality education for all. This global policy agenda set out the requirement that the countries should develop national education policies or modify their existing policy planning in the light of these international goals (UNESCO, 2002). This means a homogenous policy planning is imposed on the all the developing countries irrespective of their local situations. However, the economic and human rights arguments about education coupled with international goals of providing all children free and compulsory education in developing countries has received strong national and international support and as a result, there have been remarkable changes in the national educational policy planning in these countries such as introduction of fee-free primary or elementary education (Nudzor, 2015).

But, the situation of basic education remained problematic in Sub-Saharan Africa and South Asia and progress made by other regions also depicted uneven results even after a decade this Conference. Buchert (1995) has found 
that in 1990, the state of primary education was quite better in East Asia and Latin America compared to rest of the developing world. The situation was poor in South Asia as the relative number of out of school girls was almost identical to that enrolled. Glewe and Zhao (2006) analyzed the condition of South Asia exhibited that the majority of the population is going to miss the opportunity of primary schooling. The projection for primary school completion rate by 2015 for this region is only 87 percent. Although significant achievements have been made in this area but the gaps still exist. With a quarter of world's population South Asia has approximately a quarter of world's primary school age children who are not enrolled in education. Burnett and Felsman (2012) has reviewed the progress on the education Millennium Development Goals and Education for All Goals to 2015 and beyond and reported that due to these international goals, the situation of education has improved in the poorest countries of the world and out of school children were halved in Sub-Saharan Africa and South Asia. Bruns et al. (2003) analyzed the global status of universal primary education with the help of World Bank database and found that regions like Sub-Saharan Africa followed by South Asia had the lowest completion rates. Kant (2019) has pointed out that India has the highest number of school-going children in the world, but unfortunately the public education system of the country is denying quality education to these children. Tilak (1999) analyzed the role of education in reducing poverty in four South Asian countries namely India, Pakistan, Sri Lanka and Nepal. It was found that in Sri Lanka where Net Primary School Enrolment Ratio is 100 percent, income poverty was quite less as compared to India, Nepal and Pakistan.

The Global Education Monitoring Report 2016 highlighted that in low- and middle-income countries, almost 4 percent of the world's out of school children are expected to never enroll in education and this issue is much worrisome in the Southern Asia where 62 percent children who are out of school will never to go to school. The report highlights that India has achieved nearly universal primary Enrolments with 98 percent ratio but it still has second highest country in terms of number of children who are out of school (UNESCO, 2016). South Asia is facing a serious learning crisis at this time and over half of children leave school without learning basic skills to become productive members of the society. If the current trends continue then this region may experience serious challenges in the future like stunted economic growth, poverty, gender inequality and also diminished overall development of these nations. The national governments and international organizations are working towards the improvement of education in this region. India and Sri Lanka are two important countries in South Asian region. India is the second most populous country of the world after China and has population of 1.2 billion having a Literacy Rate 72 percent. Sri Lanka is a separate island with population of 21 million and having literacy rate of approximately 92 percent.

Both the countries gain independence almost at the same time and are very proactive for the realization of universal basic education but the progress of Sri Lanka towards universal basic education and other social sectors is quite impressive as compared to progress of India. World Bank with the help of detailed analysis of five major Millennium Development Goals in sub-national units of Sri Lanka presented a report which concluded that the country had already achieved the goal of universal primary education and recognized as a best performer in South Asia. However, the major challenges before universal primary education in this country are low quality of education and low learning levels of students (World Bank, 2005). The Government of India provides free and compulsory education from class first to class eighth only but in Sri Lanka education from primary schooling to first degree level of university education is free. The focus of this study is to analyze the development of educational planning in these countries in under the impact of international goals and also to compare the progress of these two countries towards universal primary education by highlighting the difference between different quantitative trends form year 2000 to 2015.

\section{Methodology}

The term globalization and comparative education are closely related to each other as compared to other academic fields. In most of the comparative education studies, nations are most preferred units of study and most of the times, developed countries are compared with developing countries or comparison is done between developed countries. The comparative studies among developing countries are often neglected (Wolhuter et al., 2003). In this study, two developing countries are selected for comparative analysis as India is growing rapidly in the economic field but performance of Sri Lanka in social sectors is far better than India. Both countries shared the common grounds in terms of colonial past and at present have developing economics. The countries fall under the high and medium human development level and yet struggling to provide best public services to their citizens.

In this study, Descriptive Method of educational research has been employed. This method of educational research obtains pertinent and precise information about the current status of phenomena and results in the formulation of general conclusions or principles of knowledge from the facts discovered. For analyzing the policy development in both the countries, the method of Document Analysis has been employed. Document analysis means a systematic procedure for examining or reviewing of documents related to the project or study and then interpreting these to understand the underlying concept (Bowen, 2009). It helps to identify patterns, trends and consistencies or inconsistencies in textual documents (Akanmori, 2011). The policy documents produced by both 
the countries have been critically studied to evaluate the influence of international policy perspective. The progress on primary education in both the countries have been studied in terms of literacy rate, enrolment rates, completion rates, out of school children, drop-out rates, human development index and learning outcomes. For this the method of trend analysis has been employed. Trend analysis is based on the longitudinal consideration of recorded data and considered as an interesting application of descriptive research as it is used to indicate that what has been happened in past, what the present situation reveals and on the basis of this what will happen in the near future (Best \& Kahn, 2007).

\section{National Educational Policy Planning regarding Universal Primary Education in India}

The Republic of India is a vast country in South Asia with 1.2 billion people. The economy of India is growing rapidly but the challenges such as poverty, superstitions, violence, poor public health care facilities and illiteracy are also growing side by side. India got independence in 1947 and a few months later in January 1950 the constitution of the federal Republic of India came into force. And in this constitution the importance of education was well recognized and so the principle of free and compulsory education was declared through Article 45 of the constitution. This article states that the government shall endeavour to provide free and compulsory education to children up to the age of fourteen years within a period of ten years from the commencement of the constitution. By setting a time limit to achieve the goal of free and compulsory education, India became first country to set time frame for the attainment of educational goals (King, 2016). This goal of free and compulsory education in India was to be achieved by 1960, but even today India fails to do so due to growing population and scarcity of resources. Time to time different education commissions and committees were appointed to make recommendations to realize the goal of universalizing the basic education. The first commission namely Education Commission appointed by Government of India, to examine comprehensively almost all aspects of education, was set up in 1964 under the chairmanship of Prof. D.S. Kothari. Education Commission submitted its report in 1966 and it is considered as major landmark in the history of education in India.

The Commission realized the constitutional dream of providing free and compulsory education remained unfulfilled. It has been realized that the education plays an important role in social and economic development and so suggested a Common School System of public education to provide equitable education to all children irrespective of the caste, creed and economic status of the individuals. As early as the 1960s, the Commission had observed that there is segregation in the education system in the country and for quality education in public school, it was recommended that allocations of national income towards education must be increased to realize the Constitutional promise of Education for All. Including this, other recommendations of this Commission were also of a far-reaching nature and if implemented in a holistic manner, they would have had a transformative impact on the society. The Commission gave due importance to individual and emphasized that education should act as an instrument of change to improve their condition. The Commission argued that quantitatively, education can be organized to improve social justice or to retard it which means where equality of opportunity is provided and education is deliberately used to develop more and more potential talent and to harness it to the solution of national problems (Government of India 1966).

One of the important recommendations of the Commission was Common School System which will be funded by government and equal opportunity will be provided to the children belonging to different socioeconomic status. The Commission recommended the universal provision of primary schools and also on the universal enrolment of children in the schools. It also put targets to reduce wastage and stagnation in school education within ten years and suggested to increase allocations to education. However, no Central Government have had a political will to implement these recommendations holistically and even the Plan allocations to education after 1966 actually went down in real terms (Jain, 2015). This recommendation of increased investment in education by the Commission was accepted by Government of India in its National Policy on Education in 1968. However, the expenditure on education increased very slowly. The Policy accepted that radical reconstruction of education, as recommended by the Commission, is essential for the economic and cultural development of the country, for national integration and for realizing the ideal of socialistic pattern of society. Strong emphasis has been placed on the free and compulsory education for all the children up to the age of 14 years and also to ensure that the children who get enrolled in the school should complete the prescribed course. The issues like regional imbalance in the equality of opportunity in education, girl's education, education of physically and mentally handicapped children had been addressed in this Policy (Government of India, 1968).

The Indian economy was trapped in an external debt trap by the late 1980s as the Nehruvian Model of capitalist development has failed to achieve its goal. The Government of India in early 1990s, under the influence of foreign forces and also due to debt, went in for 'Structural Adjustment Loan' from World Bank-International Monetary Fund (WB-IMF). Some of the features of this 'Structural Adjustment Package' signed by Government of India included removal of all curbs on import and exports, elimination of any kind of government interferences in the operation of free markets, privatization of the public sector like water, health, education etc. This restructuring of Indian Economy is named as Globalization and in 1985, under the impact of globalization the 
name of Ministry of Education changed to Ministry of Human Resource Development and this change implied that the purpose of education is reduced to supplying skillful human resources to corporation and nothing more than that (Jain, 2015). And in this era of globalization, there has been an increased international emphasis on the universalization of the primary education to produce skillful labor force to the industries.

The National Policy on Education 1986 and Programme of Action (1992) proved to be major statements of this influence which lay down the objectives and features of education policy of India. With the formulation of National Policy on Education, India intensified the efforts to achieve the goal of universal elementary education. For realizing the goals of socialism, democracy and secularism, the Policy emphasized the role of free and compulsory education for all. It was felt that this goal of free and compulsory education could be realized only if people from all classes of the society and from all age groups were literate. So, emphasis was put on adult education, non-formal education and education for equality. The National Policy on Education and its revised form in 1992, both ignored the basic inconsistency of ends and means to achieve the goal of universal elementary education. In 1986, the Policy declared that all children up to 14 years of age will be provided free and compulsory education by 1995 , but this lofty goal remain unfulfilled. Again in 1992, it was repeated with different time frame that before we enter twenty-first century, free and compulsory education would be provided to all children up to the age of 14 years (Dreze \& Sen, 2005).

At the same time, under the effect of globalization of Indian economy, the policy suggested non-formal, distance education and multitrack education system in the country. The Policy declared that for half of the children, in the age group of 6-14 years who are out of school, non-formal education of inferior quality shall be instituted by appointing 'instructors' in place of regular and qualified teachers (Jain 2015). It is also pointed out that this policy was designed to fit in the framework of SAP which might have been operational in India well before it was publicly announced in 1991 (Sadgopal, 2006).

The next major turning point in the history of development of education in India is signing the "World Declaration on Education for All' held at Jomtien, Thailand in 1990. This international conference on education has been organized by World Bank in association with UNDP, UNESCO and UNICEF. The Indian Government signed this document even without consulting Parliament on its major Constitutional implications (ibid). By signing this document, Indian Government agreed to reduce expenditure on education and to privatize the education sector. At the same time, this document marked a transformation in the education policy formulation in India as from now onwards this Jomtien Declaration Policy Framework would determine educational policies of Government of India. This policy transformation coincided with the beginning of New Economic Policy as the Government of India accepted that 'Structural Adjustment Loan' from WB-IMF in mid-1991 and indicated its willingness to reduce its expenditures on essential services including education. For India, the adoption of SAP and the Jomtien Declaration mark a paradigm shift in educational policy planning as the Indian Government starts reducing its allocations to education and indirectly imitate the process of privatization of elementary education (Jain 2015). However, with the involvement of international assistance in elementary education, there has been enhanced emphasis on the efforts for universalization of elementary education.

In this direction, District Primary Education Programme was launched by Central Government of India in 1994 as a major initiative to achieve the objective of universalization of primary education. DPEP is an effort by Central Govt. to decentralize the educational planning at district level and is planned in way that suits the educational needs of a particular district by having major objectives such as to provide access to all children in primary education, to reduce drop-out rates, to increase learning achievements etc. It is a part of several initiatives of Structural Adjustment Programme of the World Bank to India in 1991. The Programme is funded by IDAWorld Bank and stands as a major response to the Jomtien Declaration. However, the funding by World Bank was quite less but the conditions attached with this funding cause a serious threat to the education system of Independent India as it was the first project in primary education in which foreign aid was utilized to meet the basic needs of the people of the country. The real objective of the DPEP was to advance the neoliberal agenda of the World Bank in the field of basic education (Jain, 2015).

With the same background a new programme i.e. 'Education for All' or Sarva Shiksha Abhiyan is a flagship programme started by Government of India to provide elementary education to all children in the age group of 614 years irrespective of caste, creed, sex etc. and also to improve the quality of elementary education in the country. It has been operational since 2000-2001 and has its roots in District Primary Education Programme, 1994. It is an opportunity for improving human capabilities of all the children (Selvam 2010). The main aim of the programme is to bridge the social, gender and regional facets of education. The time bound and integrated approach has been introduced through this programme to achieve the universalization of elementary education in the country by 2010 . The programme has been considered as a national movement for qualitative and comprehensive elementary education by providing interventions such as universal access and retention, eliminating gender and social gaps in elementary education and also for improving the quality of learning at this level of education (Government of India 2000). The programme is being criticized for the promotion of privatization of elementary education and also for Education Guarantee Scheme, Alternate school etc. as these are considered as second grade teaching for children 
of the poor, Dalit, disabled and girls. The programme promotes substandard education to the needy and poor. It has also been pointed out that the programme is not implemented in the manner as the government had intended (Kumar 2006).

The Report on a Policy Framework for Reforms in Education was prepared by Special Subject Group on Policy Framework for Private Investment in Education, Health and Rural Development with Mukesh Ambani as a convener and Kumaramangalam Birla as a member and was submitted to Prime Minister's Council on Trade and Industry in April 2000. This report clearly depicted a paradigm shift in the educational planning of India and proved to be significant development in the Indian Educational Policy Making. The report realized the important role of education for producing human capital for knowledge-based society. And suggested to shape the education planning of India by taking into considerations the experiences of other countries such as China, Singapore, Sweden etc. The report emphasized that investment in primary education yields highest returns, so government should invest maximum in this level of education and make it free and compulsory. The report pointed out the skewed nature of education development in India by pointing out the skewness favoring some groups and ignoring others. Further, it is suggested that to survive in this information-based society, India needs serious reforms in its education system (Singh 2012).

The Right of Children to Free and Compulsory Education Act, 2009 commonly known as Right to Education (RTE) Act came into effect on April 10, 2010 and the act makes it a legally binding obligation of the government to provide free and compulsory education to every child from age 6 to 14 years. The $86^{\text {th }}$ Amendment in the Indian Constitution added Article $21 \mathrm{~A}$ in its which states that every child between the age of six to fourteen years has the right to free and compulsory education and this RTE Act seeks to implement this right. The Act mandates the private institutions to reserve 25 percent seats of their class strength for the children from economically weaker and disadvantaged sections of the society (Government of India 2009). It is highlighted in the Act that no child would be failed till the age of 14, infrastructure of school will be improved and the burden of this will be shared by central and state government. It also emphasized that quality of education will be improved. The Act has been critically analyzed and it has been pointed out that the Act made a dent to the education rights of the children in the country after its implementation due to the glaring gaps in the most of provisions of the Act like defining a child, ambiguous provisions on teacher eligibility, lack of critical parameters to check the quality of education etc. (Jha \& Parvati 2014).

\section{National Policy Planning regarding Universal Primary Education in Sri Lanka}

Sri Lanka, officially known as the Democratic Socialist Republic of Sri Lanka, is a neighboring country of India. It is an island country in South Asia with a population of 20.26 million. Sri Lanka gained independence in 1948 and at that time it has well developed education system. The Education Ordinance 1939 and subsequent amendments provide the legislative framework on equality of educational opportunity and also to implement the right to education. The Free Education Bill was passed in 1940s and it paved the way for free and compulsory education in vernacular medium from kindergarten to university. After that the Free Education Act 1945 came and it was intended to provide education in English Medium to the children from poor families. In 1946, Sri Lanka had literacy rate of 57.8 percent. The government has made education one of its top priorities and played a larger role in its development and amelioration. The Constitution of Sri Lanka has a legal framework on education in its chapter on 'Principles of State Policy'. The legal framework states that the state is pledged to establish in Sri Lanka a democratic Socialist Society, the objective of which include the complete eradication of illiteracy and the assurance of all persons of the right to universal and equal access to education at all levels. The impressive literacy rate of Sri Lanka has been accomplished with the help of government's commitment to education. The British Colonial Period (1796-1948) shaped the development of education system in the country. After independence, the free education system of the country was reinforced by several policies that enabled poor children to receive education. The schemes like free text book, mid-day meal, free uniforms etc. were initiated to improve school Enrolment and school attendance.

A decade before the World Conference on Education for All, Sri Lanka has been cited as an outstanding example of low-income country that has attained universal primary school Enrolment and gender parity in education. These factors along with high adult literacy, low child mortality etc. indicated good outcomes of development in Sri Lanka due to public investment in social sectors (Athurupane 2009). In Sri Lanka, Education was free in vernacular medium government school and in 1945 the 'Free Education Act' made education free in English medium schools for poor children. From 1945-1977, the education system in Sri Lanka flourished as the Government has given due importance to the democratization of education at all levels and proper public investment in education sector. The education reforms in 1972 gave priority to democratization of education, improving the quality of learning, restructuring the school system etc. In 1978, the principle of Universal and Compulsory Education is built into the chapter on Directive Principles of State Policy and Fundamental Duties in the Constitution of the Democratic Socialist Republic of Sri Lanka. The $13^{\text {th }}$ Amendment to Constitution in 1987 emphasized decentralization in education so that the administrative structure of education should be restructured 
according the local needs and requirements to increase the efficiency of the system.

Globalization in Sri Lanka has started with liberalization of economy in 1977. In this year, there is a change in the government and President J.R. Jayewardene took major decision regarding the drastic change in the economy of Sri Lanka and country opens its doors to the globalization. The implementation of Structural Adjustment Programmes in 1977, and its impact on social sector expenditure resulted in stagnation in Enrolment and literacy rates. In 1979, a policy decision regarding external assistance to private schools has been taken by the government (Gunawardena 2010/11). The percentage of GDP allocated to education has decreased from 4 percent of GDP in 1960s to below 3 percent in 1970s and the trend continues till now as only 1.7 percent of GDP has been allocated to education in 2013. The national policy planning has shifted its focus from local to global and now the educational policies are developed under the influence of international policy planning. Most of policies need foreign funds for their implementation as Government has reduced public expenditure on the education. The donor agencies especially World Bank start influencing policy making in education after supporting education in this country. It has been pointed out that the educational policies in the country are developed by following the foreign models of developed countries and without giving any consideration to the ground realities (ibid). This influence of international organizations and international policy planning in Sri Lanka can be assessed from the various policy documents.

Regarding educational planning in the country, National Education Commission was established after youth unrest and its main purpose was to recommend and advice President on continuous educational policy planning keeping in view the changing needs of the society. It was established under the National Education Commission Act No. 19 of 1991. The Act, 1991 includes four parts in which Part I deals with the establishment of National Education Commission by the President to declare National Education Policy. In other parts of the Act, the composition of the Commission, duties of the members of the Commission etc. has been described. The first report of Commission came out in 1992, in this National Education Commission (NEC) gave much importance to improve the quality of education at primary level of education. It has been observed that participation in primary education is quite high but there is need of efforts to make participation to 100 percent. The report set out nine national goals regarding the planning of education in the country. The policy statement of President Kumaratunga regarding the improvement in education and importance of education in the overall development policy of Sri Lanka was delivered in 1995 and this policy asserted that the decline in the percentage of public resources from 1960s to 1990s has resulted in the decline in the quality of education and also in inequities.

In 1995, the Action Oriented Strategy towards a National Education Policy was produced and this policy put stress on the democratization of education to ensure universal and equal access to education for the children in 514 years of age. This policy also emphasized the need for improvement in the quality of general education. At the same time, the policy suggested alternative structures of schooling for the drop-outs and non-starters to provide them adequate and meaningful learning. The strategy also emphasized improvements in the quality of education (National Education Commission, 1995).

The Regulations on Compulsory Education enacted in 1997 and enforced with effect from 1 January, 1998 under the education reforms has been considered as an important piece of legislation in the education system of the country. These regulations compel all children between the age group of 5 to 14 years to attend a school or an alternative educational institution recognized by Ministry of Education. The upper age limit has been extended from 14 to 16 years from the year 2016 by the new regulations and parents will be considered guilty if they fail to send their children to the school (Kirinde, 2016).

The General Education Reforms, 1997 reviewed the education system of the country and highlighted that approximately 14 percent of children of 5-14 years of age were out of school and several regional disparities in this number also exist. The education system is failed to produce pupils with right kind of knowledge, understanding, skills and attitude required to become productive members of the society. That is why restructuring of education system and reforms become an urgent priority. The major objective of these reforms is to create an education system that will enable the citizens to become well-informed, knowledgeable and practically skilled. It has also been pointed that these reform for their implementation will depend on foreign fund and this will not continue for a long time so GDP for education should be increased in the coming years. Regarding compulsory education, the reforms recommended that regulations regarding compulsory education, effective from January 1998, require parents to ensure admission and attendance of their children in the schools (National Education Commission, 1997).

The Primary Education Planning Project (PEPP) in the Ministry of Education published Five Year Plan for Primary Education (FYPPE) to achieve universal primary education in the country and also to improve the quality of education after the launch of initial short-term actions plans in 1997. The plan was launched with the involvement of major stakeholders of the in Primary Education at National and Provincial level and it was sponsored by Department for International Development (DFID), United Kingdom. The plan resonates with the principles of EFA National Action Plan and addresses four of the EFA goals Goal 2,3 (excluding adults), 4 and 6. The main aims of the plan was to extend the educational opportunity and to improve the quality of primary 
education in the country. One of the four goals of the plan were to ensure the initial enrolment of all boys and girls at the official primary education entry age of 5+ by 2004, thereby laying the base for their completion of primary education stage (Little, 2003).

The quality of education and learning outcomes are considered unsatisfactory and these need urgent attention from policy makers. In 2003, NEC made recommendations to amend legislation regarding the establishment of private school and international schools in the country. It is further suggested that this kind of private investment in education will prove helpful to increase the percentage of GDP expenditure on education. It has been suggested that establishment of private schools for basic education will be proved to be additional investment in this level of education and will be helpful for the recovery of general education system. These proposals strongly recommend private sector investment and foreign aid in the development of education sector in the country (National Education Commission 2003).

This Education Sector Development Framework and Programme (ESDFP) is considered as the most important policy supporting the education system of the country by addressing the issues of from the school to national level through a blend of bottom-up and top-down approaches. The ESDFP has been launched in 2006 for the period of 2006-2010 with the help of World Bank and other development partners. The country has made an impressive progress in many spheres of education but due to the dissatisfaction over issues related to equity, quality and relevance of education and changing demographics demanded education reforms. These reforms in ESDFP will ensure education for all and also helps in the achievement of MDGs and EFA goals. The strategies will be introduced to ensure 95 percent of children under the age of 14 years should complete compulsory phase of education by 2015 (MoE, 2006). Education Sector Development Framework and Programme-II (2012-2016) also known as Transforming School Education as the Foundation of Knowledge Hub Project is the second phase of ESDFP starts in 2012 with the aim of enhancing equitable access and quality of primary and secondary education to provide the foundation for the knowledge based economic and social development of the country (MoE, 2012).

\section{Progress of India and Sri Lanka towards Universal Primary Education}

The comparison of progress towards the goals of universal primary education in India and Sri Lanka can be made by comparing their Literacy Rates, Gross Enrolment Ratio, Net Enrolment Ratio, Drop-out Rates, number of outof-school children, their expenditure on primary education as a percentage of total expenditure on education, Human Development Index value and learning outcomes of the students. The required data is collected form UNESCO Institute of Statistics, Department of Census and Statistics, Sri Lanka and publications of Ministry of Human Resource Development, India. The following discussion and data compare the progress of India and Sri Lanka on the various dimensions listed below:

\subsection{Literacy Rates of India and Sri Lanka}

The following table shows the literacy rate of India and Sri Lanka in the age group of 7 years and above and from the data it can be concluded that Sri Lanka has a better picture than India, it has already achieved literacy rate of more than 95 percent as compared to 73 percent of India. The high literacy rate of females in Sri Lanka contributed a lot in successful family planning and in turn in better social development of country. The country also has lowest poverty ratio in the South Asian region mainly due to the high literacy rates. Sri Lanka has an impressive literacy rate among male and female population, on the other hand 64.6 percent literacy rate of females in India is a matter of serious concern. The low literacy rate among female population in India is responsible for a number of social evils such as rapid growth of population, high child mortality rate etc. On the other hand, high literacy rate among females has contributed to decline in population growth in Sri Lanka (Chatterjee 2011). The average literacy rate of Sri Lanka is better than the world literacy rate which was 89.65 percent in 2011. At the time of independence, Sri Lanka has a literacy rate of 60 percent and has done a wonderful job in reducing the percentage of illiterate people from 40 percent in 1948 to only 5 percent in 2012 despite of the long civil war in the country.

Table 1: Literacy Rates of India and Sri Lanka

\begin{tabular}{|c|c|c|c|c|c|c|}
\hline \multirow{2}{*}{ Country $\downarrow$} & \multicolumn{3}{|c|}{2001} & \multicolumn{3}{|l|}{ Year } \\
\hline & Total & Male & Female & Total & Male & Female \\
\hline India * & 64.8 & 75.3 & 53.7 & $73.00(2011)$ & 80.9 & 64.6 \\
\hline Sri Lanka** & 91.1 & 92.6 & 89.7 & $95.6(2012)$ & 96.8 & 94.6 \\
\hline
\end{tabular}

Source: * Educational Statistics at a Glance, $2014 * *$ Website of Department of Census and Statistics, Sri Lanka (Data for 10 years of age and over)

5.2 Gross Enrolment Ratio in Primary Education of India and Sri Lanka

Gross Enrolment Ratio (GER) of Sri Lanka was high in the year 1990 and in 2015 it is less than GER of India. High GER of India shows that over age children enrolled in elementary schooling. The trends in GER of India shows an increase from 1990 to 2010 and then a decrease in value in 2015. On the other hand, GER of Sri Lanka was 109.85 in 1990 and followed a descending trend till 2010 and then there is a rise in 2015 with a value of 
101.68

Table 2: Gross Enrolment Ratio in Primary Education of India and Sri Lanka

\begin{tabular}{|l|l|l|l|l|}
\hline Country $\downarrow$ & $\mathbf{1 9 9 0}$ & $\mathbf{2 0 0 1}$ & $\mathbf{2 0 1 0}$ & $\mathbf{2 0 1 5}$ \\
\hline India & 91.44 & 94.41 & 109.18 & 108.60 \\
\hline Sri Lanka & 109.85 & 107.77 & 99.7 & 101.68 \\
\hline
\end{tabular}

Source: UNESCO Institute of Statistics

5.3 Net Enrolment Ratio in Primary Education of India and Sri Lanka

Net Enrolment Ratio in Sri Lanka represents a stable and nearly universal Enrolment in primary education as compared to India's performance in this aspect. The Net Enrolment Ratio of India shows an upward trend form the year 2000 onwards but even in 2013 the value is only 92.26. These values vary in different states like Kerala, Karnataka, and some other states have higher NER than the national average and Bihar, Arunachal Pradesh, Meghalaya, Jharkhand have values lower than the national average (Bhat, 2013).

Table 3: Net Enrolment Ratio in Primary Education of India and Sri Lanka

\begin{tabular}{|l|l|l|l|l|l|}
\hline Country & $\mathbf{1 9 9 0}$ & $\mathbf{2 0 0 0 - 2 0 0 5}$ & $\mathbf{2 0 1 0}$ & $\mathbf{2 0 1 3}$ & $\mathbf{2 0 1 5}$ \\
\hline India & -- & $79.77(2000)$ & 91.02 & 92.26 & - \\
\hline Sri Lanka & 87.3 & $97.25(2005)$ & 94.93 & 96.38 & 98.94 \\
\hline
\end{tabular}

Source: UNESCO Institute of Statistics

\subsection{Drop-out Rates}

The major challenge in universal elementary education in India is its high drop-out rates. As per the data available, the drop-out rate is quite high in India as compared to Sri Lanka. Sri Lanka has almost universal retention rate. In India, the drop-out rate to the last grade of primary education shows an impressive decrease from 2013 to 2015 , but still to maintain universal retention of children in universal primary education more efforts are required at immediate basis.

Table 4: Drop-out Rates to the last Grade Primary Education in India and Sri Lanka

\begin{tabular}{|l|l|l|l|}
\hline Country & $\mathbf{2 0 0 1}$ & $\mathbf{2 0 1 3}$ & $\mathbf{2 0 1 5}$ \\
\hline India & 38.63 & 18.16 & 9.83 \\
\hline Sri Lanka & 2.21 & 1.79 & 1.61 \\
\hline
\end{tabular}

Source: UNESCO Institute of Statistics

\subsection{Out of School Children}

India has highest number of out-of-school children in the year 2010 mainly due to its high population, however the number of out-of-school children in India reduced from more than 19 million in 1990 to less than 5 million in 2010. And this number again increased up to more than five million children of primary school age children were out of school in India in 2011. The latest number for out-of-school children in India was available for the year 2013 and from this number it can be concluded that India had approximately 3 million children of primary school age who were out of school. On the other hand, the number of out-of-school children in Sri Lanka followed an upward trend from 1949 in 2001 to 85544 in 2010, after that it started to decrease and country had less than sixteen thousand children who were out of school in 2016.

Table 5: Number of Out of School Children

\begin{tabular}{|l|l|l|l|}
\hline Country $\downarrow$ & $\mathbf{2 0 0 1}$ & $\mathbf{2 0 1 0}$ & $\mathbf{2 0 1 3}$ \\
\hline India & 19170670 & 4808268 & 2897747 \\
\hline Sri Lanka & 1949 & 85544 & 61084 \\
\hline
\end{tabular}

Source: World Bank

5.6 Expenditure on Education

There is a crucial role of investment on education on the overall quality of schooling. The expenditure on primary education as the percentage of total expenditure on education is a measure of government's commitment to this level of education. In 2010, the government expenditure on education as a percentage of GDP in India was 3.42 percent and for Sri Lanka it was only 1.72 percent. India spends more on education as compared to Sri Lanka but due to increasing population and other factors it fails to achieve universal enrolment and retention in compulsory education. On the other hand, the quality of education is deteriorating in Sri Lanka mainly due to low spending on education.

5.7 HDI Value of India and Sri Lanka

The Human Development Index (HDI) is a composite statistic of life expectancy, education, and per capita 
income indicators, which are used to rank countries into four tiers of human development. It is known as best known composite index of social and economic well-being. Sri Lanka with its HDI value of 0.766 falls under 'high human development' category with Human Development Index Rank of 73 while India falls under 'medium human development category on rank 131. Sri Lanka's HDI value is higher than the average HDI value of South Asia region which is 0.621 . The main factors that contribute to the better performance of Sri Lanka as compared to India in HDI value are achievements in universal primary education and better health care facilities. The ranking of Sri Lanka indicates that improvements in human development can occur even without fast economic growth.

Table 6: HDI Value, Ranks and Category of India and Sri Lanka

\begin{tabular}{|l|l|l|l|l|}
\hline Country & $\mathbf{2 0 0 0}$ & $\mathbf{2 0 0 5}$ & $\mathbf{2 0 1 0}$ & $\mathbf{2 0 1 5}$ \\
\hline India & $\begin{array}{l}0.407 \\
(124-M e d i u m)\end{array}$ & $\begin{array}{l}0.619 \\
(128-M e d i u m)\end{array}$ & $\begin{array}{l}0.519 \\
(119-\text { Medium })\end{array}$ & $\begin{array}{l}0.624 \\
(131- \\
\text { Medium })\end{array}$ \\
\hline Sri Lanka & $\begin{array}{l}0.741 \\
(89-M e d i u m)\end{array}$ & $\begin{array}{l}0.743 \\
(99-M e d i u m)\end{array}$ & $\begin{array}{l}0.658 \\
(91-M e d i u m)\end{array}$ & 0.766 \\
& $(73-$ High $)$ \\
\hline
\end{tabular}

Source: Human Development Reports (Various Years)

\subsection{Learning Outcomes}

India refused to participate in international assessment of student's performance after 2009. The data on learning outcomes in India is primarily based on the Annual Status of Education Reports (ASER) and these reports are prepared by non-governmental organization known as Pratham. It has been pointed out by the World Development Report 2018 that in India half of students in Grade 5 could not solve a two-digit subtraction and more than 80 percent of Grade 2 students could not read a single word of short text and could not perform a two-digit subtraction. And the recent report states that in 2018, only 73 percent of students at the end of elementary education could read atleast a Standard II level text and this percentage remained unchanged from the year 2016. Regarding the basic athematic abilities, the trend is almost similar. In 2018, the percentage of children from Class 3 who can do a twodigit subtraction remain almost same means 27.6 in 2016 to 28.1 in 2018 . The percentage of students of Class $5^{\text {th }}$ who can do division was 26 in 2016 and it has inched up slightly to 27.8 percent in 2018 .

National Assessment of Learning Outcomes 2015 was conducted for Class 4 students to test the cognitive skills in three subjects-first language Sinhala and Tamil, second language English and Mathematics. The mean scores of students in Sinhala and Tamil language were 64.47 and 61.57, and from the scores it can be concluded that overall performance of students in the first language was above satisfactory. However, the performance of students in second language i.e. English was also considered satisfactory but the mean score of students was only 53.53, which is quite less as compared to first language means score value. Regarding Mathematics, the overall performance was also considered satisfactory as the national mean score of students was 62.25 . The findings of this assessment also revealed that there was disparity in the achievement in all three subjects in relation to provincial performance, school type, gender and medium of instruction (NEREC, 2016).

\section{Conclusion}

Education plays a critical role in the enrichment of lives of individuals and also in the development of countries. The role of primary education is recognized by the global community and serious efforts have been initiated for the universalization of primary education. Under the impact of globalization, global policy agenda is imposed on all the developing countries. The comprehensive concept of education has been reduced and now the emphasis is shifted from 'education' to 'learning/basic learning needs/literacy'. It is treated as commodity and the development of critical thinking ability has been replaced by skill development. The international as well as national policy documents support private involvement in the provision of education either directly or in the form of Public-Private partnerships. In India, the concept of 'education as a fundamental right' is modified according the needs of markets and then implemented in the form of RTE Act, 2009, which has made a dent to the educational rights of children in the country. The policies and programmes, such as DPEP and Sarva Shiksha Abhiyan in India and Five-Year Plan for Primary Education (FYPPE) and Education Sector Development Framework and Programme in Sri Lanka, have been launched with the help of international assistance to extend the educational opportunity and to improve the quality of education. A tremendous progress has been registered in the quantitative expansion of primary education after such policies, but even today many students are out of school and usually these students belong to the marginalized sections of the society.

Among South Asian countries, Sri Lanka presents an impressive record in the achievement of the goal of universal primary education. The better status of primary education in Sri Lanka can be seen by looking at the literacy rate of the country which is nearly universal. The high literacy rate among female population in Sri Lanka, stable Gross Enrolment Ratio, almost universal Net Enrolment Rate in primary education and negligible drop-out rates are some of the reasons which makes Sri Lankan Education System ideal. On the other hand, low female literacy rate, high Gross Enrolment ratio, high dropout rates, high number of out of school children and poor 
learning outcomes in India are the serious challenges in the realization of the goal of universal primary education. India devotes major portion of its public education expenditure on elementary education, but the quality of education in most of the government schools in country is low. Majority of the children even after completing primary education are functionally illiterate. India has a fast-growing economy but the level of human development is low in India as compared to Sri Lanka. The better performance of Sri Lanka in education sector is the main reason for its high human development levels. Sri Lanka's performance in primary education is good but for the improvement of quality of education at this level, the country needs to increase its public expenditure on education. Disparities in the learning outcomes of the primary school children in Sri Lanka is a serious concern and need immediate attention from the government and policy planners. From the policy analysis, it has been observed that both the countries are dependent upon external aid for the goal of universal primary education, so it is matter of serious concern that how these countries would sustain their efforts for universalization of primary education in the absence of international financial assistance.

\section{References}

Akanmori, H. (2011). A critical analysis of the activities of the Canadian International Development Agency (CIDA) to promote equity and access in the achievement of Millennium Development Goals (MDGs) for education in Ghana: 2005-2010 (Master Thesis) Retrieved from http://hdl.handle.net/1807/30068

ASER Centre (2019). Annual Status of Education Report (Rural) 2018 Provisional. New Delhi: ASER Centre. Retrieved from http://img.asercentre.org/docs/ASER\%202018/Release\%20Material/aserreport2018.pdf

Athurupane, H. (2009). The pearl of Great Price: Achieving Equitable Access to Primary and Secondary Education and Enhancing Learning in Sri Lanka (English). Create Pathways to Access: Research Monograph No. 29, Washington DC: World Bank. from http://documents.worldbank.org/curated/en/588171468302710856/The-pearl-of-great-price-achievingequitable-access-to-primary-and-secondary-education-and-enhancing-learning-in-Sri-Lanka

Best, J. \& Kahn, J.V. (2007). Research in Education. New Delhi: Prentice Hall.

Bhat, S.A. (2013). Millennium Development Goals: Achieve Universal Primary Education from Indian Perspective. International Journal of Scientific \& Research Publication, 3(11), 1-9. Retrieved from www.ijsrp.org.

Bowen, G.A. (2009). Document Analysis as Qualitative Research Method. Qualitative Research Journal, 9(2), 27-40.

Bruns, B., Mingat A., \& Rakotomalala, R. (2003). Achieving Universal Primary Education by 2015: A Chance for Every Child. Washington, DC: World Bank. Retrieved from http://siteresources.worldbank.org.

Buchert, L. (1995). The Concept of Education for All: What Has Happened After Jomtien. International Review of Education, 41(6), 537-549.

Burnett, N. \& Felsman, C. (2012). Post- 2015 Education MDGs. Washington DC \& London: Results for Development Institute \& Overseas Development Institute (ODI).

Chatterjee, B. (2011). Education for All-the Indian Saga. New Delhi: Lotus Press.

Dreze, J., \& Sen. A. (2013). An Uncertain glory-India and its Contradiction. New Delhi: London Publication.

Glewe, P., \& Zhao, M. (2006). Attaining Universal Primary Schooling by 2015: An Evaluation of Cost Estimates. In Joel E. Cohen, David E. Bloom \& Martin B. Malin (Eds.). Educating All Children: A Global Agenda (pp. 415-456). Cambridge: American Academy of Arts and Sciences.

Government of India (1966). Education and National Development. Report of the Education Commission. Retrieved from https://archive.org

Government of India (1968). National Policy on Education 1968. Retrieved from https://mhrd.gov.in/sites/upload_files/mhrd/files/document-reports/NPE-1968.pdf

Government of India (2000). Sarva Shiksha Abhiyan: A Programme for Universal Elementary Education: Framework for Implementation. New Delhi: Ministry of Human Resource Development.

Government of India (2009). The Right of Children to Free and Compulsory Education Act, 2009.New Delhi: Ministry of Human Resource Development.

Gunawardena, C. (2010/2011). Translating Education Policy into action in Sri Lanka. Sri Lanka Journal of Social Sciences 2010/2011 33/34 (1\&2)

Inter-Agency Commission (1990). World Declaration on Education for All and Framework for Action to Meet Basic Learning Needs. New York: UNICEF

Jain, N. (2015). Education under Globalisation: Burial of the Constitutional Dream. Delhi: Aakar Books.

Jha, P., \& Parvati, P. (2014). Assessing Progress on Universal Elementary Education in India: A Note on Some Key Constraints. Economic \& Political Weekly, XLIX (16), 44-51.

Kant, A. (2019, March 25). Education reform needs a systematic approach. Hindustan times. Retrieved from https://www.hindustantimes.com 
King, K. (2016). The Global Targeting of Education and Skill: Policy, History and Comparative Perspectives. Compare,46(6), 952-975.

Kirinde, C. (2016). Education Compulsory for Children between 5 to 16 years: Parents guilty of an offence if they fail to ensure this. The Sunday Times. Retrieved from http://www.sundaytimes.lk/160501/news/educationcompulsory-for-children-between-5-and-16-years-191731.html

Kumar, R. (2006). Equality, Quality and Quantity-Mapping the Challenge Before Elementary Education in India. In R. Kumar (Ed.) The Crisis of Elementary Education in India (pp, 13-56). New Delhi: Sage Publications.

Little, A.W. (2003). Education for All Policy and Planning: Lessons from Sri Lanka. DFID Education Research Paper No. 46. Retrieved from https://ageconsearch.umn.edu/record/12883

MoE (2006). Education Sector Development Framework and Programme 2006-2010. Colombo: Ministry of Education.

MoE (2012). Education Sector Development Framework and Programme-II:2012-2016. Colombo: Ministry of Education

Mondal, A. \& Mete, J. (2012). Right to Education. New Delhi: APH Publishing Corporation.

Ministry of Human Resource Development (2014). Educational Statistics at a Glance. New Delhi: Bureau of Planning, Monitoring and Statistics.

National Education Commission (1997). Reform in General Education. Retrieved from http://nec.gov.lk/category/policies/

National Education Commission (1995). An action-oriented strategy towards a national policy. Sri Lanka: NEC.

National Education Commission (1997). Reforms in General Education. Sri Lanka: NEC.

National Education Commission (2003). Envisioning Education for Human Development, Proposal for a National Framework on General Education in Sri Lanka. Colombo: Sri Lanka.

NEREC (2016). National Report: National Assessment of Achievement of Students Completing Grade 4 in Year 2015 in Sri Lanka. Colombo: National Educational Research and Evaluation Centre.

Nudzor, H.P. (2015). Taking Education for All Goals in Sub-Saharan Africa to Task: What's the Story so far and what is Needed Now. Management in Education, 29(3), 105-111. Retrieved from http://mie.sagepub.com Doi:10.1177/0892020615584105

Sadgopal, A. (2006). Dilution, Distortion and Diversion: A Post-Jomtien Reflection on Education Policy. In R. Kumar (Ed.) The Crisis of Elementary Education in India (pp, 92-136). New Delhi: Sage Publications.

Singh, R. (2012) Development of Elementary Education in India, Brazil and South Africa: A Comparative Study. M.Ed. Dissertation, Punjabi University, Patiala.

The Constitution of India (1950). Article 45. Retrieved from https://www.refworld.org/docid/3ae6b5e20.html

Tilak, J.B.G. (1999). Education and Poverty in South Asia. Prospects, XXIX (4), 517-533.

UNESCO (2002). EFA Global Monitoring Report 2002: Education for All-Is the World on Track. Paris: United Nations Educational, Scientific and Cultural Organization.

UNESCO (2016). Global Education Monitoring Report 2016: Education for People and Planet- Creating Sustainable Futures for All. Paris: United Nations Educational, Scientific and Cultural Organization.

United Nations (2001). Road map towards the implementation of the United Nations Millennium Declaration. New York: United Nations.

United Nations (2015). Transforming our world: the 2030 Agenda for Sustainable Development. New York: United Nations.

United Nations (2017). The Sustainable Development Goals Report, 2017. New York: United Nations.

Wolhuter, C. C., Steyn, S. C., \& Steyn, H. J. (2003). Learning from south-south comparison: The education system of South Africa and Madagascar. South African Journal of Education, 23(1), 29-35.

World Bank (2005). Sri Lanka: Attaining the Millennium Development Goals in Sri Lanka, How Well and What Will it Take to Reduce Poverty, Child Mortality \& Malnutrition \& to Increase School Enrollments \& Completion? Washington DC: World Bank.

Websites

https://data.worldbank.org

http://uis.unesco.org

http://www.statistics.gov.lk/

http://mhrd.gov.in

http://nec.gov.lk/category/policies/

http://www.hdr.undp.org/ 